\title{
Water pollution along the Mahul Creek of Mumbai, India - Study of Physico-chemical Properties
}

\author{
Pravin U. Singare ${ }^{1, \star}$, M. V. A. Ansari ${ }^{1}$, N. N. Dixit ${ }^{2}$ \\ ${ }^{1}$ Department of Chemistry, Bhavan's College, Munshi Nagar, Andheri (West), \\ Mumbai - 400058, India \\ ${ }^{2}$ Department of Chemistry, Maharashtra College, Jahangir Boman Behram Marg, Nagpada, \\ Mumbai - 400008, India \\ *E-mail address: pravinsingare@gmail.com
}

\begin{abstract}
The present study was performed for the period of one year from January 2013 to December 2013 in order to understand the physico-chemical properties of Mahul Creek water. From the results of our study it was observed that the annual average COD level was $362.09 \mathrm{ppm}$ which was far higher than the maximum tolerable level of $250 \mathrm{ppm}$ set for inland surface water as well as for marine coastal water. The annual average conductivity was found to be $6122.81 \mu \mathrm{S} \mathrm{cm}^{-1}$ which was very much above the conductivity limit for inland surface water of $1000 \mu \mathrm{S} \mathrm{cm}^{-1}$ set by Central Pollution Control Board $(C P C B)$ for propagation of fisheries. The annual average total alkalinity level was recorded as 166.25 ppm, which according to the UN Department of Technical Cooperation for Development (1985) was found to be strongly alkaline. The annual average hardness level of the creek water was found to be $2488.65 \mathrm{ppm}$ which was above the limit of $300 \mathrm{ppm}$ set by ISI. From the results of the present investigation it seems that the time has come to implement proper effluent water treatment techniques and enforcement of pollution control by the regulatory authority on the indiscriminate discharge of industrial wastewater into water bodies.
\end{abstract}

Keywords: industrial effluents; physico-chemical properties; creek water; Mahul Creek; Mumbai

\section{INTRODUCTION}

In India due to rapid industrialization, urbanization and development of slum areas with improper environmental planning have resulted in heavy discharge of domestic sewage and industrial effluents into the water bodies. Most of the industries in India are situated along the river banks for easy availability of water and also disposal of the wastes. It is found that onethird of the total water pollution in India comes in the form of industrial effluent discharge, solid wastes and other hazardous wastes [1-16].

Out of this, a large portion can be traced to the processing of industrial chemicals and to the food products industry. The surface water is the main source of industries for waste disposal. Untreated or allegedly treated effluents have increase the level of surface water pollution up to 20 times the safe level in 22 critically polluted areas of the country. It is found 
that almost all rivers are polluted in most of the stretches by some industry or the other. The industrial wastes often contain a wide range of contaminants such as petroleum hydrocarbons, chlorinated hydrocarbons and heavy metals, various acids, alkalis, dyes and other chemicals which greatly change the $\mathrm{pH}$ of water.

The waste also includes detergents that create a mass of white foam in the river waters. All these chemicals are quite harmful or even fatally toxic to fish and other aquatic populations [17-21]. These wastes also include various toxic chemicals, acids, alkalis, dyes, detergents, pesticides and agrochemicals which greatly affect the physico-chemical properties of water bodies. Therefore, a better understanding of physico-chemical properties like $\mathrm{pH}$, conductivity, alkalinity, salinity, hardness, Chemical Oxygen Demand (C.O.D) etc. in the water bodies seem to be particularly important issues of present day research on pollution assessments [22-32]. According to one study it was estimated that Mumbai city of India itself discharges around $2200 M L D$ of waste to the coastal waters [33].

In view of present day by day increasing pollution level along most of the creeks and rivers in Mumbai, in the present study attempt was made to conduct the systematic study of physico-chemical properties of water samples collected along the Mahul creek of Mumbai. It is expected that the results of our study will help greatly in understanding the water pollution status along the Mahul creek which receives heavy pollution load from the surrounding refineries, agrochemical and other industries and also domestic effluent from the surrounding slum areas.

\section{EXPERIMENTAL}

\section{1. Study Area}

Mahul creek $\left(19^{\circ} 01^{\prime} \mathrm{N} \& 72^{\circ} 53^{\prime} \mathrm{E}\right)$ lying on the east coast of Mumbai along the Arabian sea, is situated in Chembur suburban the north eastern corner of Mumbai about $15 \mathrm{~km}$ from Victoria Terminus (presently known as Chhatrapati Shivaji Terminus). The temperature of the area ranges between $13{ }^{\circ} \mathrm{C}$ to $39{ }^{\circ} \mathrm{C}$. The south west monsoon (June to mid-October) brings rain to the area which is recorded maximum $747 \mathrm{~mm}$ during July. The climate is humid and relative humidity ranges between 29 to $96 \%$ [34].

\section{2. Sampling}

The study on pollution status along the Mahul creek of Mumbai was performed for the period of one year from January 2013 to December 2013. The grab samples were collected in polythene bottles of $2.5 \mathrm{~L}$ along different locations of the creek. The bottles were thoroughly cleaned with hydrochloric acid, washed with distilled water to render free of acid, rinsed with the water sample to be collected and then filled with the sample leaving only a small air gap at the top.

The sample bottles were stoppard and sealed with paraffin wax. The grab samples thus collected were mixed to give gross sample. Such samples were drawn and analysed monthly for the entire year. The samples were analyzed for their physico-chemical parameters so as to get the seasonal variation in pollution level along the Mahul Creek.

\section{3. Physico-Chemical Parameters studied}

The water samples collected were analyzed for Total Dissolved Solid (TDS), Total Suspended Solids (TSS), Total Solids (TS), Chemical Oxygen Demand (COD), phosphates, 
temperature, $\mathrm{pH}$, electrical conductivity, salinity, cyanide, total hardness, fluoride and total alkalinity. The techniques and methods followed for analysis and interpretation were according to the standard procedures [35-39].

\section{RESULTS AND DISCUSSION}

The experimental data on physico-chemical properties of the water samples collected along the Mahul Creek of Mumbai is presented in Table 1. The annual average values of various physico-chemical properties of the water samples are graphically represented in Figures 1-3. The temperature of the creek water was found to vary in the range of $25.2{ }^{\circ} \mathrm{C}$ to $29.3{ }^{\circ} \mathrm{C}$, with an annual average temperature of $27.3^{\circ} \mathrm{C}$. The $\mathrm{pH}$ value of creek water was minimum of 6.22 in the month of August to maximum of 7.30 in the month of April with an annual average value of 6.89. The TDS content of water was low of $2996.12 \mathrm{ppm}$ in the month of April to $4890 \mathrm{ppm}$ in the month of January. The annual average TDS content of the Creek water was found to be $4199.5 \mathrm{ppm}$ which was very much above the conductivity limit of $2100 \mathrm{ppm}$ set by $C P C B$ for inland surface water [40]. On the basis of $T D S$ values, waters can be classified as, desirable for drinking (up to $500 \mathrm{mg} / \mathrm{L}$ ), permissible for drinking (up to $1,000 \mathrm{mg} / \mathrm{L}$ ), useful for irrigation (up to $2,000 \mathrm{mg} / \mathrm{L}$ ), not useful for drinking and irrigation (above 3,000 mg/L) [41].Therefore the creek water can be considered unfit for drinking and irrigation purpose. The TSS content of the creek water was minimum of $18.22 \mathrm{ppm}$ in the month of July to maximum of $41.01 \mathrm{ppm}$ in the month of March. The annual average TSS level was found to be $31.20 \mathrm{ppm}$. The minimum COD was obtained as $68.77 \mathrm{ppm}$ in the month of November and maximum of $645.22 \mathrm{ppm}$ in the month of May. The annual average $C O D$ was calculated as $362.09 \mathrm{ppm}$ which was more than the maximum tolerable COD level of $250 \mathrm{ppm}$ set for inland surface water as well as for marine coastal water [42]. The concentration of phosphate in the creek water was found to vary in the range of 6.19 to $112.85 \mathrm{ppm}$, having the average annual concentration of $51.18 \mathrm{ppm}$.

Table 1. Physico-Chemical Properties of the Mahul Creek water.

\begin{tabular}{|c|c|c|c|c|c|c|c|c|c|c|c|c|}
\hline $\begin{array}{l}\text { Sampling } \\
\text { Months/Year } \rightarrow\end{array}$ & 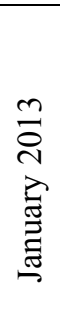 & 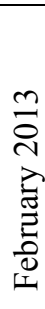 & $\begin{array}{l}m \\
\stackrel{\sim}{n} \\
\overline{0} \\
\dot{0} \\
\sum\end{array}$ & $\begin{array}{l}\frac{m}{0} \\
\frac{0}{\tilde{D}} \\
\frac{\bar{z}}{2}\end{array}$ & $\begin{array}{l}\frac{m}{2} \\
\stackrel{\vec{\lambda}}{\Sigma} \\
\Sigma\end{array}$ & $\begin{array}{l}\text { n } \\
\text { ○ } \\
0 \\
\Xi \\
\Xi\end{array}$ & 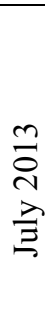 & 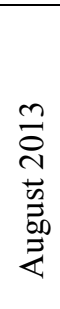 & 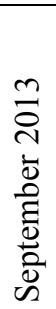 & $\begin{array}{l}\stackrel{m}{0} \\
\text { I. } \\
\stackrel{0}{0} \\
\stackrel{0}{0} \\
0\end{array}$ & 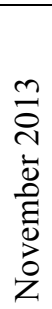 & 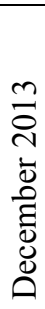 \\
\hline Temperature $\left({ }^{\circ} \mathrm{C}\right)$ & $\begin{array}{l}0 \\
\ddot{n}\end{array}$ & $\begin{array}{l}n \\
\infty \\
\sim\end{array}$ & กे & $\vec{a}$ & $\vec{a}$ & $\underset{\stackrel{\sim}{\sim}}{\stackrel{0}{0}}$ & $\underset{\infty}{\sim}$ & $\underset{⿱ 亠}{\Delta}$ & $\stackrel{\circ}{\stackrel{\sim}{N}}$ & $\begin{array}{l}0 \\
\ddot{\sim}\end{array}$ & $\begin{array}{l}0 \\
\dot{\sim}\end{array}$ & 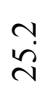 \\
\hline $\mathrm{pH}$ value & $\begin{array}{l}\infty \\
\widehat{\sigma}\end{array}$ & $\stackrel{\circ}{\underset{1}{2}}$ & ఫे & 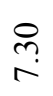 & $\stackrel{8}{\circ}$ & ?ֶ. & $\begin{array}{l}\bar{\infty} \\
0\end{array}$ & ֶָ & ñ & ঙิ & $\begin{array}{l}\infty \\
\infty \\
0\end{array}$ & $\stackrel{ }{N}$ \\
\hline
\end{tabular}




\begin{tabular}{|c|c|c|c|c|c|c|c|c|c|c|c|c|}
\hline $\begin{array}{l}\text { Total Dissolved } \\
\text { Solid (ppm) }\end{array}$ & $\begin{array}{l}8 \\
\stackrel{0}{0} \\
\stackrel{+}{+} \\
\dot{+}\end{array}$ & $\frac{\bar{a}}{\dot{m}}$ & $\begin{array}{l}\hat{\sigma} \\
\dot{0} \\
\dot{0}\end{array}$ & $\begin{array}{l}\text { ते } \\
\text { ¿ें }\end{array}$ & 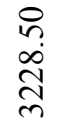 & 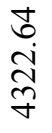 & $\begin{array}{l}\infty \\
\infty \\
\infty \\
0 \\
0 \\
\infty\end{array}$ & 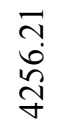 & 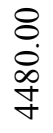 & 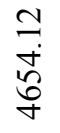 & 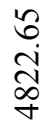 & 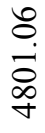 \\
\hline $\begin{array}{l}\text { Total Suspended } \\
\text { Solids (ppm) }\end{array}$ & $\underset{m}{\stackrel{8}{m}}$ & ¿े. & $\underset{\vec{\sigma}}{\vec{\gamma}}$ & 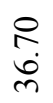 & 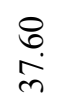 & $\begin{array}{l}\infty \\
\infty \\
\infty \\
\infty\end{array}$ & $\begin{array}{l}\tilde{N} \\
\infty\end{array}$ & $\begin{array}{l}\vec{j} \\
\dot{\lambda}\end{array}$ & $\stackrel{8}{9}$ & 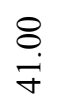 & $\underset{\substack{q \\
\infty}}{\infty}$ & $\begin{array}{l}\bar{\sigma} \\
\infty \\
\infty\end{array}$ \\
\hline TS (ppm) & $\begin{array}{l}\stackrel{8}{a} \\
\stackrel{a}{\sigma}\end{array}$ & $\begin{array}{l}n \\
\hat{n} \\
\stackrel{n}{n}\end{array}$ & 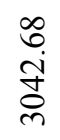 & 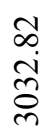 & 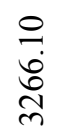 & $\frac{\tilde{n}}{+}$ & $\begin{array}{l}0 \\
\dot{n} \\
\infty \\
\infty\end{array}$ & 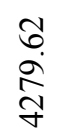 & $\begin{array}{l}\stackrel{8}{\circ} \\
\stackrel{9}{+}\end{array}$ & 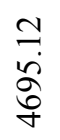 & 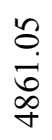 & 命 \\
\hline $\mathrm{COD}(\mathrm{ppm})$ & $\stackrel{0}{\stackrel{1}{*}}$ & $\begin{array}{l}\infty \\
\infty \\
\mathbb{N} \\
\text { J }\end{array}$ & $\begin{array}{l}n \\
i \\
\infty \\
i n\end{array}$ & $\begin{array}{l}\infty \\
\infty \\
\dot{ \pm}\end{array}$ & 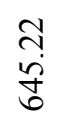 & $\begin{array}{l}\infty \\
\stackrel{\infty}{\infty} \\
\infty \\
\infty\end{array}$ & $\begin{array}{l}n \\
\text { के }\end{array}$ & 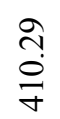 & $\begin{array}{l}\text { ปे } \\
\text { ஓे }\end{array}$ & $\underset{i}{i}$ & $\hat{\hat{0}}$ & $\stackrel{?}{\stackrel{?}{i}}$ \\
\hline $\mathrm{PO}_{4}{ }^{2-}(\mathrm{ppm})$ & $\hat{m}$ & $\hat{n}$ & $\vec{\sim}$ & $\stackrel{\infty}{=}$ & $\frac{9}{6}$ & $\frac{\infty}{n}$ & $\begin{array}{l}n \\
\dot{5} \\
\stackrel{0}{0}\end{array}$ & $\begin{array}{l}\infty \\
\infty \\
ٍ\end{array}$ & $\begin{array}{l}0 \\
\stackrel{1}{0}\end{array}$ & $\stackrel{m}{\dot{y}}$ & $\stackrel{\frac{1}{m}}{m}$ & 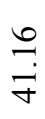 \\
\hline $\begin{array}{c}\text { Electrical } \\
\text { Conductivity } \\
\left(\mu \mathrm{S} \cdot \mathrm{cm}^{-1}\right)\end{array}$ & $\begin{array}{c}8 \\
\stackrel{0}{n} \\
\text { in }\end{array}$ & $\begin{array}{l}m \\
\infty \\
\infty \\
\infty \\
\infty\end{array}$ & $\begin{array}{l}= \\
= \\
\infty \\
\dot{\sigma}\end{array}$ & $\begin{array}{l}\stackrel{0}{2} \\
\stackrel{n}{0} \\
\stackrel{+}{+}\end{array}$ & $\begin{array}{l}8 \\
\stackrel{\leftrightarrow}{1} \\
\infty \\
+\infty\end{array}$ & $\begin{array}{l}\stackrel{m}{c} \\
\text { in } \\
\text { i⿱ }\end{array}$ & 㐫 & $\underset{\substack{f \\
\dot{f}}}{\text { f }}$ & $\begin{array}{l}\frac{7}{+} \\
\stackrel{\infty}{\pi} \\
\overparen{\sigma}\end{array}$ & $\begin{array}{l}\tilde{i} \\
\ddot{8} \\
\stackrel{8}{2}\end{array}$ & $\begin{array}{l}\vec{b} \\
\dot{+} \\
\stackrel{r}{r}\end{array}$ & 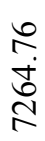 \\
\hline Salinity (ppm) & $\begin{array}{l}\infty \\
\dot{\infty} \\
\dot{n}\end{array}$ & f̊. & $\stackrel{m}{?}$ & $\underset{\substack{+i}}{i}$ & $\begin{array}{l}\stackrel{2}{n} \\
\ddot{i}\end{array}$ & $\begin{array}{l}\text { त̦ } \\
0 \\
0\end{array}$ & $\begin{array}{l}\infty \\
\infty \\
\dot{n} \\
n \\
n\end{array}$ & $\begin{array}{l}\stackrel{0}{n} \\
\stackrel{+}{*} \\
\stackrel{\sim}{n}\end{array}$ & 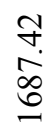 & 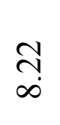 & 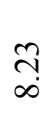 & $\stackrel{?}{f}$ \\
\hline Cyanide (ppm) & ? & $\stackrel{2}{0}$ & $\begin{array}{l}0 \\
0 \\
0\end{array}$ & $\overrightarrow{\widetilde{\sigma}}$ & 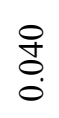 & $\stackrel{0}{0}$ & $\stackrel{m}{0}$ & $\stackrel{\tilde{\sigma}}{0}$ & $\stackrel{+}{\circ}$ & ? & $\stackrel{0}{\circ}$ & $\ddot{\Xi}$ \\
\hline $\begin{array}{l}\text { Total Hardness } \\
\quad(\mathrm{ppm})\end{array}$ & $\stackrel{2}{\stackrel{2}{8}}$ & $\begin{array}{l}\exists \\
\stackrel{+}{+} \\
\stackrel{+}{q}\end{array}$ & 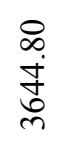 & $\begin{array}{l}\vec{b} \\
\stackrel{0}{*} \\
\stackrel{f}{f}\end{array}$ & $\begin{array}{l}\stackrel{2}{\$} \\
\dot{\infty} \\
\infty \\
\infty\end{array}$ & 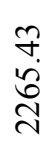 & 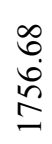 & $\begin{array}{l}8 \\
8 \\
\stackrel{0}{0} \\
\infty \\
-\infty\end{array}$ & 节 & $\begin{array}{l}m \\
\stackrel{m}{\infty} \\
\infty\end{array}$ & $\begin{array}{l}\text { f. } \\
\stackrel{0}{a}\end{array}$ & 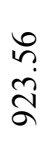 \\
\hline $\begin{array}{l}\text { Total Alkalinity } \\
\quad(\mathrm{ppm})\end{array}$ & 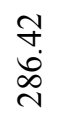 & $\begin{array}{l}\bar{a} \\
\infty \\
=\end{array}$ & $\stackrel{\stackrel{n}{f}}{\stackrel{亠}{I}}$ & $\begin{array}{l}n \\
0 \\
0 \\
=\end{array}$ & $\begin{array}{l}2 \\
\infty \\
\stackrel{0}{=}\end{array}$ & : & $\begin{array}{l}0 \\
\infty \\
\infty \\
\infty\end{array}$ & ก̃ & $\frac{2}{2}$ & $\begin{array}{l}\text { mे } \\
\stackrel{\infty}{\infty}\end{array}$ & $\begin{array}{l}\infty \\
\stackrel{\infty}{\infty} \\
\stackrel{\infty}{N}\end{array}$ & 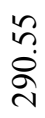 \\
\hline
\end{tabular}




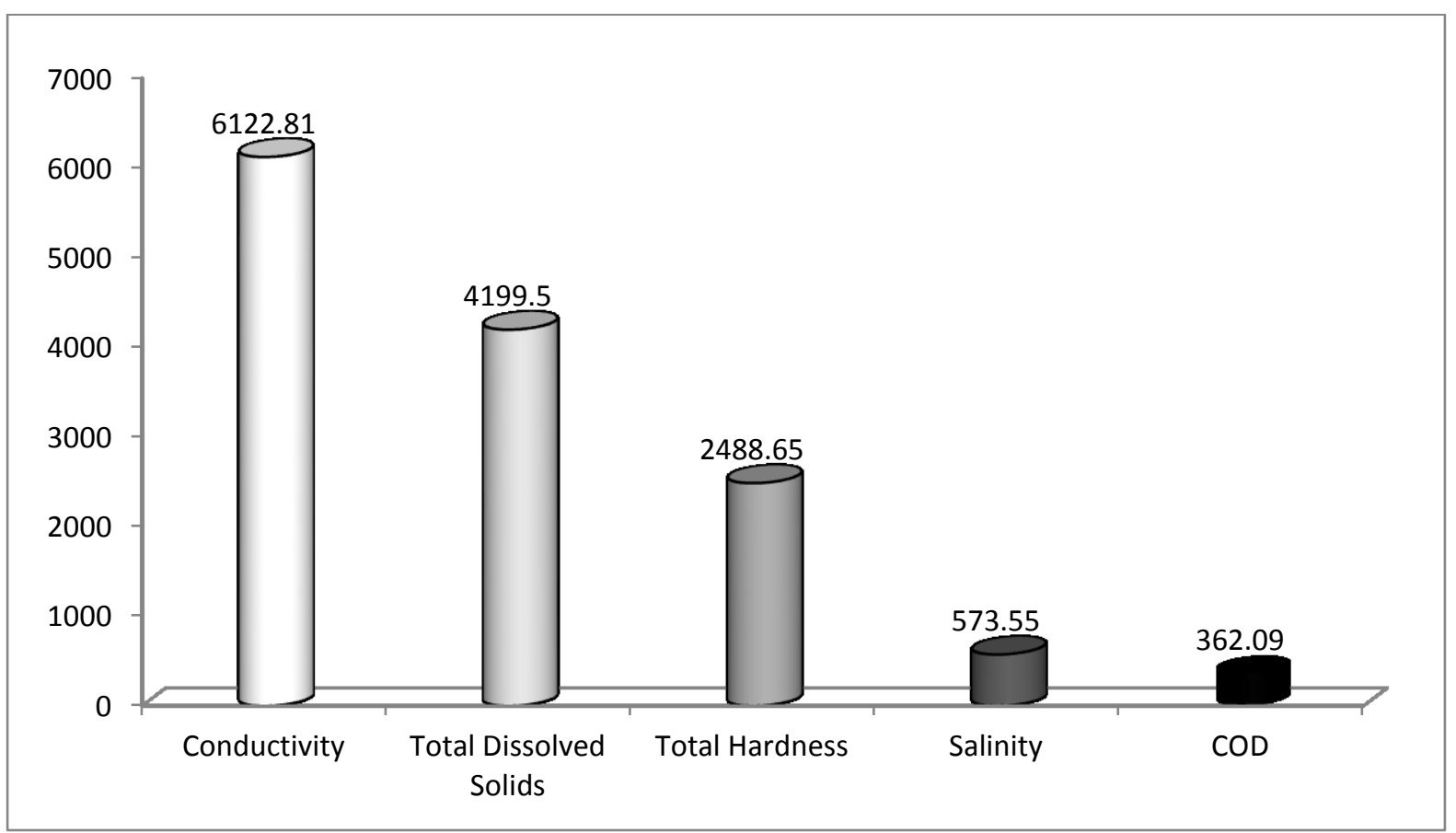

Table 1. Annual average conductivity, TDS, Total Hardness, salinity and COD values of Mahul Creek water. (All values except conductivity are expressed in ppm, conductivity value expressed in $\left.\mu S \cdot \mathrm{cm}^{-1}\right)$.

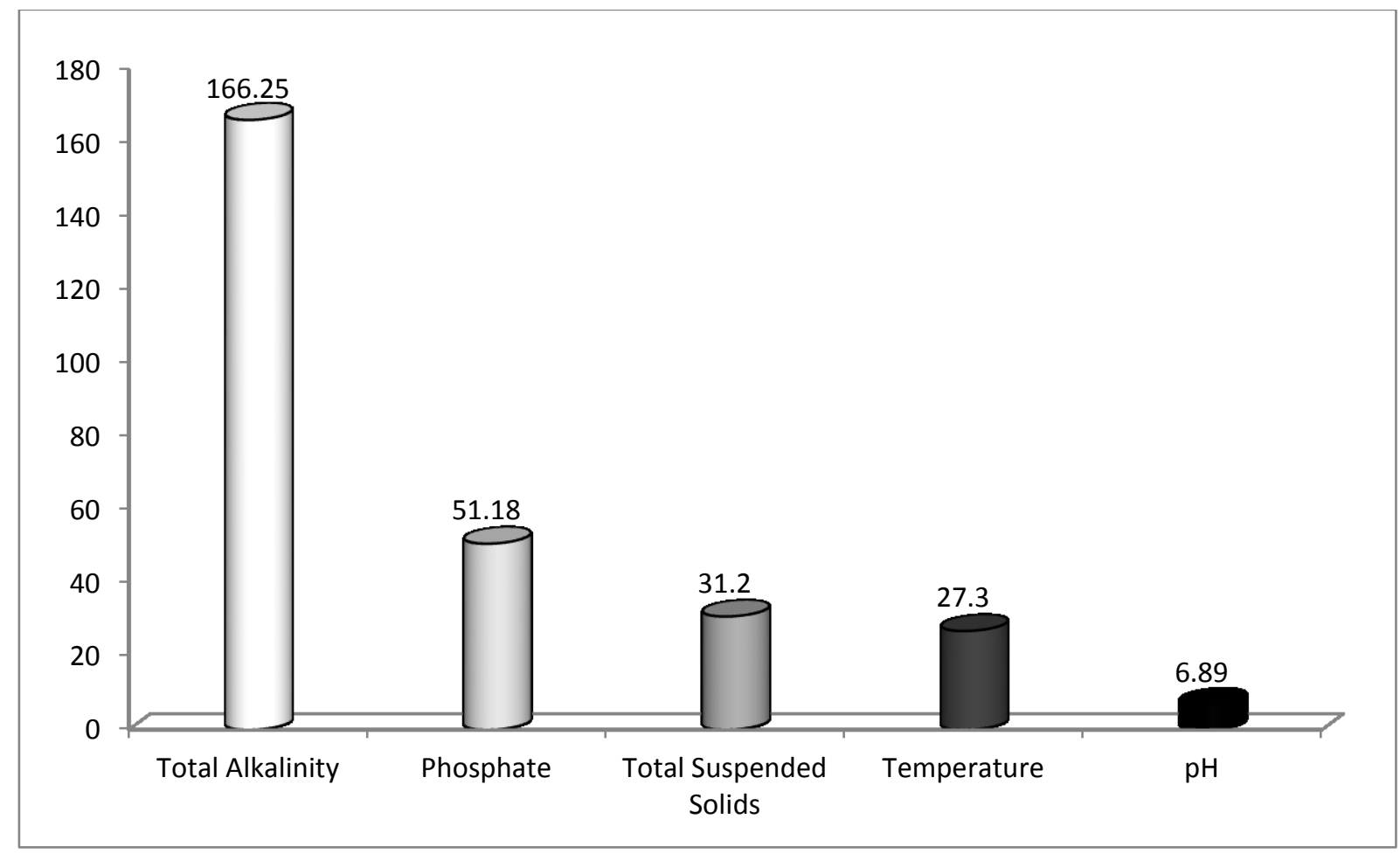

Table 2. Annual average conductivity, total alkalinity, phosphate, TSS, temperature and $\mathrm{pH}$ values of Mahul Creek water. (All values except temperature and $p H$ are expressed in ppm, temperature in ${ }^{\circ} \mathrm{C}$ ) 


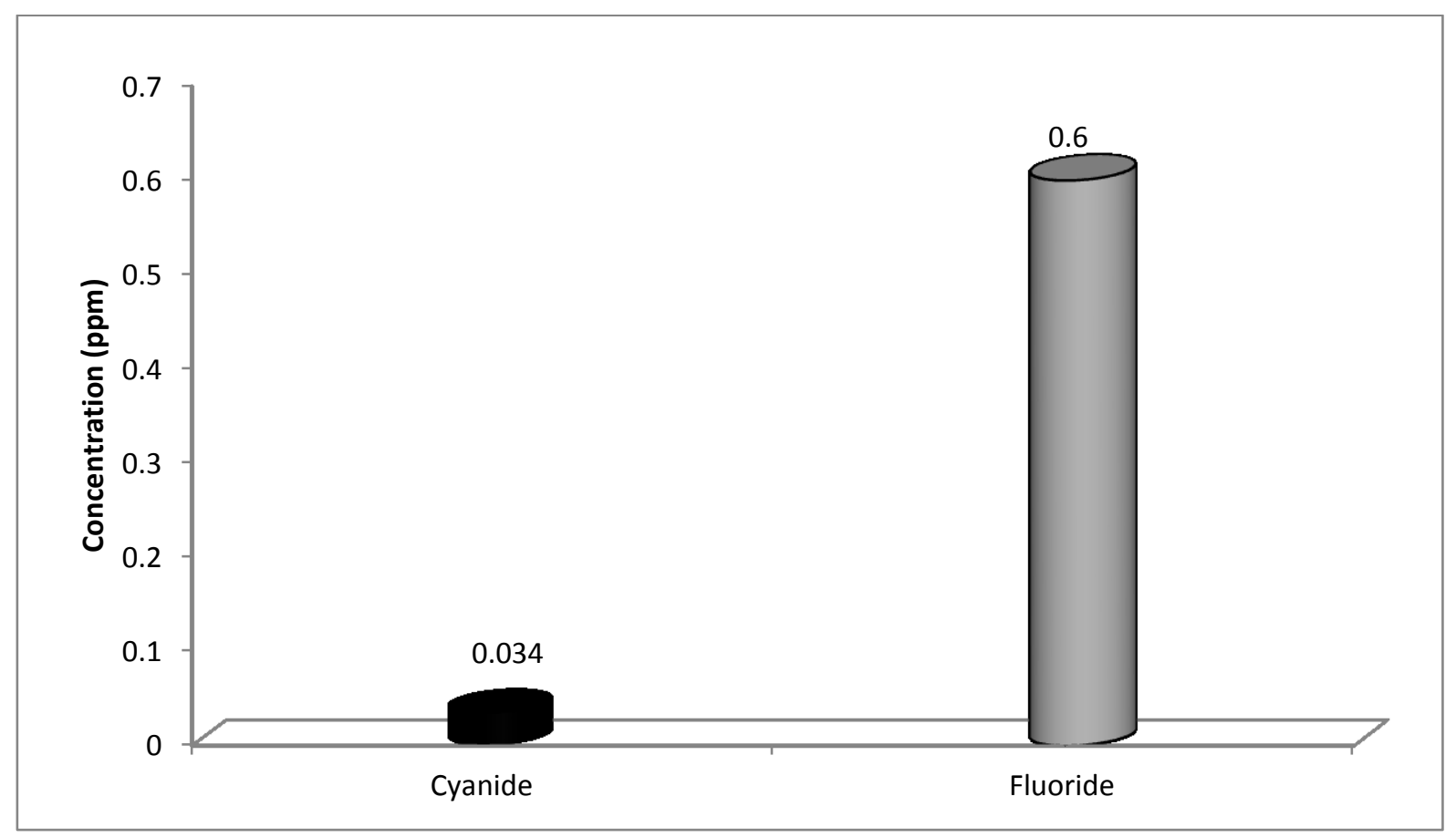

Table 3. Annual average cyanide and fluoride contents in the Mahul Creek water.

The electrical conductivity of creek water was in the range of 4464.56 to $7334.01 \mu \mathrm{S}$ $\mathrm{cm}^{-1}$. The annual average conductivity was found to be $6122.81 \mu \mathrm{S} \mathrm{cm}$ which was very much above the conductivity limit for inland surface water of $1000 \mu \mathrm{S} \mathrm{cm}^{-1}$ set by $C P C B$ for propagation of fisheries [40]. The salinity, cyanide and fluoride content of the creek water were found to vary in the range of 3.68 to $1687.42 \mathrm{ppm}, 0.010$ to $0.04 \mathrm{ppm}$ and 0.1 to $1.0 \mathrm{ppm}$ respectively.

The annual average salinity, cyanide and fluoride content were calculated as 573.55 ppm, $0.034 \mathrm{ppm}$ and $0.60 \mathrm{ppm}$ respectively. The total hardness of the creek water was minimum of $889.33 \mathrm{ppm}$ in the month of October and maximum of $4883.9 \mathrm{ppm}$ in the month of May, having annual average hardness level of $2488.65 \mathrm{ppm}$. Kannan [43] has classified water on the basis of hardness values in the following manner: $0-60 \mathrm{mg} / \mathrm{L}$, soft, $61-120$ $\mathrm{mg} / \mathrm{L}$, moderately hard, $121-160 \mathrm{mg} / \mathrm{L}$, hard and greater than as $180 \mathrm{mg} / \mathrm{L}$ very hard. Using these criteria, the creek water can be considered as very hard. The overall total hardness values were very much above the limit of $300 \mathrm{mg} / \mathrm{L}$ set by ISI [44]. The observed higher values of hardness indicate the presence of basic salts - sodium and potassium in addition to those of calcium and magnesium [45].

The total alkalinity content was found to vary in the range of $86.66 \mathrm{ppm}$ to $290.55 \mathrm{ppm}$ with the average annual alkalinity level of $166.25 \mathrm{ppm}$. According to the UN Department of Technical Cooperation for Development [46], water having alkalinity up to $50 \mathrm{mg} / \mathrm{L}$ is considered to be weak alkaline, up to $100 \mathrm{mg} / \mathrm{L}$ is considered to be medium alkaline, while if the alkalinity is above $200 \mathrm{mg} / \mathrm{L}$ it is considered as strongly alkaline.

Hence based on results of the present investigation, the creek water was medium to strongly alkaline [47-54]. 


\section{CONCLUSION}

With the rapid industrialization in the country, environment pollution by industrial waste has increased tremendously. The discharge of waste water from industries such as oil and surfactants industries, tanneries, pulp and paper, textile, petroleum, chemical industries etc. pollute water bodies. Nature has an amazing ability to cope up with small amount of waste water and pollution, but it would be hazardous or harmful if billions of gallons of waste water produced everyday are not treated before releasing them back to the environment. The quantities and characteristics of discharged effluent vary from industry to industry depending on the water consumption and average daily product. Characterization of raw effluent from oil and surfactants industries revealed a wide variation in the effluent quality and quantity over time, characteristic of the different processing stages employed in product manufacturing. Thus, physico-chemical treatment of these effluents is required to bring them into the biodegradable zone and ensure local sewer standards are meeting.

\section{References}

1. P.U. Singare, R.S. Lokhande, A.G. Jagtap, International Journal of Global Environmental Issues, 11(1), 28-36 (2011).

2. P.U. Singare, R.S. Lokhande, A.G. Jagtap, Interdisciplinary Environmental Review, 11(4), 263-273 (2010).

3. R.S. Lokhande, P.U. Singare, D.S. Pimple, World Environment, 1(1), 6-13 (2011).

4. R.S. Lokhande, P.U. Singare, D.S. Pimple, Resources and Environment, 1(1): 13-19 (2011).

5. R.S. Lokhande, P.U. Singare, D.S. Pimple, International Journal of Ecosystem, 1(1), 1-9 (2011).

6. S.K. Sasamal, K.H. Rao, U.M. Suryavansi, International J. Remote Sensing, 28(19), 43914395 (2007).

7. A. Nagaraju, S. Suresh, K. Killham, K. Hudson-Edward, Turkish J. Eng. Env. Sci., 30(4), 203-219 (2006).

8. T. Rajaram, A. Das, Futures, 40, 56 (2008).

9. M.D. Zingade, M.M. Sabnis, A.V. Mandalia, B.N. Desai, Mahasagar Bull. Natn. Inst. Occeonagr., 13, 99 (1980).

10. P.U. Singare, S.S. Dhabarde, International Letters of Chemistry, Physics and Astronomy, 3 (2014) 56-63.

11. P.U. Singare, S.S. Dhabarde, International Letters of Chemistry, Physics and Astronomy, 3 (2014) 48-55.

12. P.U. Singare, S.S. Dhabarde, International Letters of Chemistry, Physics and Astronomy, 3 (2014) 40-47.

13. P.U. Singare, S.S. Dhabarde, International Letters of Chemistry, Physics and Astronomy, 3 (2014) 32-39. 
14. P.U. Singare, S.S. Dhabarde, International Letters of Chemistry, Physics and Astronomy, 3 (2014) 8-15.

15. P.U. Singare, S.S. Dhabarde, International Letters of Chemistry, Physics and Astronomy, 3 (2014) 16-23.

16. P.U. Singare, S.S. Dhabarde, International Letters of Chemistry, Physics and Astronomy, 3 (2014) 24-31.

17. A. Aghor, 'Chemicals make Thane creek the worst polluted water body'. Daily $D N A$. August 14, 2007. Mumbai, India. Obtained through the Internet:

http://www.dnaindia.com/mumbai/report_chemicals-make-thane-creek-the-worstpolluted-waterbody_1115439 [accessed 01/03/2010].

18. D. Patil, 'A lot's fishy about our creek and lake fish'._Daily Times of India. March 22, 2009. Mumbai, India. Obtained through the Internet: http://timesofindia.indiatimes.com/city/thane/A-lots-fishy-about-our-creek-and-lakefish/articleshow/4298566.cms [accessed 01/03/2010].

19. A. Kumar, Pol. Arch. Hydrobiol., 18, 469 (1996).

20. P.U. Singare, M.S. Talpade, Interdisciplinary Environmental Review, 14(1), 59-68 (2013).

21. R.D. Chakravarty, P. Ray, S.B. Singh, Indian J. Fish., 6, 186 (1959).

22. P. U. Singare, R.M. Mishra, M.P. Trivedi, Resources and Environment, 1(1), 32-41 (2011).

23. P.U. Singare, M.P. Trivedi, R.M. Mishra, D.V. Dagli, Interdisciplinary Environmental Review, 13(2/3), 220-243 (2012).

24. P.U. Singare, M.P. Trivedi, R.M. Mishra, Marine Science, 1(1), 22-29 (2011).

25. P. U. Singare, R.M. Mishra, M.P. Trivedi, Interdisciplinary Environmental Review, 13(4), 245-268 (2012).

26. P.U. Singare, R.S. Lokhande, S.S. Bhattacharjee, Interdisciplinary Environmental Review, 12(02), 95-107 (2011).

27. P.U. Singare, R.S. Lokhande, K.U. Naik, Interdisciplinary Environmental Review, 12(3), 215-230 (2011).

28. P.U. Singare, R.S. Lokhande, K.U. Naik, Interdisciplinary Environmental Review, 11(01), 90-107, (2010)

29. P.U. Singare, R.S. Lokhande, S.V. Bhanage, Interdisciplinary Environmental Review, 12(01), 1-11 (2011).

30. P.U. Singare, R.S. Lokhande, P.P. Pathak, Interdisciplinary Environmental Review, 11(01), 38-56, (2010).

31. P.U. Singare, M.S. Talpade, D.V. Dagli, V.G. Bhawe, Water $R \& D, 2(3), 79-84$ (2012).

32. P.U. Singare, M.S. Talpade, V.G. Bhawe, D.V. Dagli, Research Journal of Pharmaceutical, Biological and Chemical Sciences, 3(4), 545-551 (2012). 
33. M.D. Zingde, K. Govindan, Health status of coastal waters of Mumbai and regions around. In: Environmental Problems of Coastal Areas in India (ed. V.K. Sharma), Bookwell Publishers., New Delhi, pp. 119-132 (2001).

34. A. Verma, S. Balachandran, N. Chaturvedi, V. Patil, Zoos' Print Journal, 19(9), 15991605 (2004).

35. F.H. Rainwater, L.L. Thatchar, 'Methods for Collection and Analysis of Water Samples' U.S. Geol. Surv. Water Supply Papers, 1454, pp. 1-301 (1960).

36. E. Brown, M.W. Skougstad, M.J. Fishman, 'Methods for Collection and Analysis of Water Samples for Dissolved Minerals and Gases', Techniques of Water Resources Investigations of the U.S. Geological Survey, 160, Book 5, Chapter A1 (1970).

37. ICMR, Indian Council of Medical Research, Manual of Standards of Quality for Drinking Water Supplies (1975).

38. J.D. Hem, 'Study and Interpretation of Chemical Characteristics of Natural Water', 3 rd edition U.S. Geological Survey, Washington (1985).

39. American Public Health Association ( $A P H A)$ 'Standard Methods for Estimation of Water and Wastewater', $19^{\text {th }}$ edition, American Water Works Association, Water environment Federation, Washington, (1995).

40. CPCB (2012) Standards for classification of inland surface water for propagation of wild life, Fisheries. Available at:

http://www.wbphed.gov.in/main/Static_pages/guidelinevalues.php (accessed on 10/05/2013).

41. L.V. Wilcox, Classification and Use of Irrigation Waters, US Dept. Of Agricultural Science, Grc, 966 (1955).

42. General Standards for Discharge of Environmental Pollutants in Inland Surface Water Part-A: Effluents, The Environment (Protection) Rules (1986) Available at: http://www.cpcb.nic.in/GeneralStandards.pdf (assessed on November 2011).

43. K. Kannan, Fundamentals of Environmental Pollution. S. Chand and Company Ltd., New Delhi, India (1991).

44. Indian Standard Institute (ISI), Drinking Water Specification (1991).

45. C. Moundiotiya, R. Sisodia, M. Kulshreshtha, A.L. Bhatia, J. Environmental Hydrology, 12, Paper 24, pp. 1-7 (2004).

46. UN Department of Technical Cooperation for Development, The use of non-conventional water resources in developing countries. Natural Water Resources Series No. 14. United Nations DTCD, New York (1985).

47. Omprakash Sahu, International Letters of Natural Sciences 7 (2014) 35-43.

48. Pravin U. Singare, M. V. A. Ansari, N. N. Dixit, International Letters of Natural Sciences 10 (2014) 69-78.

49. Pravin U. Singare, M. V. A. Ansari, N. N. Dixit, International Letters of Natural Sciences 10 (2014) 79-88

50. Piotr Daniszewski, Ryszard Konieczny, International Letters of Chemistry, Physics and Astronomy 4 (2013) 91-97. 
51. Piotr Daniszewski, Ryszard Konieczny, International Letters of Chemistry, Physics and Astronomy 4 (2013) 98-104.

52. Piotr Daniszewski, International Letters of Chemistry, Physics and Astronomy 4 (2012) 119-124.

53. Emil Cyraniak, Piotr Daniszewski, Beata Draszawka-Bołzan, International Letters of Chemistry, Physics and Astronomy 5 (2012) 88-95.

54. Emil Cyraniak, Piotr Daniszewski, Beata Draszawka-Bołzan, International Letters of Chemistry, Physics and Astronomy 5 (2012) 96-103. 